\title{
An Overview of Methods of Reliability and Availability Analysis based on Software Architecture
}

\author{
Neeraj Kumar Sharma \\ Amity University, Noida
}

\author{
ArunPrakashAgrawal \\ Amity University, Noida
}

\begin{abstract}
When we talk about the User acceptance testing of the software then two quality matrices come into our mind. They are Reliability \& Availability. These two parameters are the most important measures for evaluating the quality of the software system and represents user-oriented view of software quality. Reliability and availability must be engineered into software from the onset of its development, andpotential problems must be detected in the early stages, when it is easier and less expensive to implement modifications. For this reason, a method is needed for analyzing software architecture with respect to reliability and availability. In this paper, we survey and examine different methods of reliability \& availability analysis based on software architecture.
\end{abstract}

\section{Keywords:}

Reliability and availability analysis, Software architecture,Software components

\section{INTRODUCTION}

Software systems are increasingly entering consumers' everyday life. These systems are often highly complicated and distributed to different platforms over wired or wireless networks. A small error in the software sub system can cause a failure in the complete system that leads to disastrous failures which differ in their impact depending on the operations of an organization. Hence these systems must demonstrate high reliability and availability.

Reliability is defined here as the probability of the failure-free operation of a software system for a specified period of time in a specified environment [1]. Availability is used to indicate the probability of a system or equipment being in operating condition at any time $t$, given that it was in operating condition at $t=0$. Reliability and availability are often defined as attributes of dependability, which is the ability to deliver service that can justifiably be trusted [2]. From an architecture point of view, reliability and availabilityare execution qualities of a software system. Several measures are traditionally used for reliability and availability, such as mean time to failure (MTTF), mean time to repair (MTTR) and failure rate. The traditional views and measures, however, might not scale up to the needs placed on today's complex systems by their multiple stakeholders. Different stakeholders, such as end user maintainers, and developers might have different requirements for the value of reliability and availability indicators. Therefore, reliability and availability must be approached from a more global perspective.

Reliability and availability predictions are the challenging tasks due following reasons.
- It is difficult to analyze software reliability and availability due to uncertain parameters like failure rates \& repair rates.

- The models generally assume that once a fault is discovered it is removed immediately i.e. software's have instantaneous repair time. The reality is that applications executing in the field can take significant amount of time may be days or weeks to get a fault removed.

- The problem, which is generally faced, is the quality of the failure data. For example repeat failures generally occur due to the fact that faults are not removed instantaneously.

- Another problem is that operational profile testing is generally ignored i.e. it is assumed that the software is going to be tested in the same manner that it is used in the field, which is not true in practice.

Several analysis or prediction methods have been developed during recent decades for different types of purposes and by different communities. Consequently, they have different definitions and measures for reliability, architecture, inputs, outputs, notations, assumptions, users, etc. Here,the paper is comparing the architecture-based reliability and availability analysis methods and techniques. The purpose is to find a method or a set of methods that can be applied to today's complex software systems, at the architecture level, as well as to discover the shortcomings of methods. Section 2describes the comparison framework for analysis methods. This framework is used to compare the selected characteristics of the reliability and availability analysis methods collected from the literature. Section 3gives a brief overview of reliability and availability prediction approaches. Section 4represents the comparison of methods and techniques for reliability \& availability prediction and Section 5presents the results of comparison. Finally,in section 6, the conclusions are summarized.

\section{A COMPARATIVE FRAMEWORK FOR RELIABILITY AND}

\section{AVAILABILITY ANALYSIS METHODS}

The framework has four categories for methods comparison. These categories have various elements and the questions related to the each element. The framework is shown in table 1. The framework describes the characteristics required for the analysis methods. The categories of the framework are based on the NIMSAD (Normative Information Model-based Systems Analysis and Design) framework [4]. NIMSAD classifies the method elements into four categories: context, user, method content, and evaluation. In the context category, the method is examined from the angle of the problem situation, whereas in the user category, the method is examined from the viewpoint of the intended method users. In the third category, the focus of the examination is the content 
of the method itself. The last category, which is validation, focus on the evaluation of the method context, user, and content. It validates the maturity of the method and the results of the method.

Table 1.A Comparative Framework for Reliability and Availability Analysis Method [4]

\begin{tabular}{|c|c|c|}
\hline Category & Elements & Questions \\
\hline \multirow{6}{*}{ Context } & Goal & What is the goal of the analysis method? \\
\hline & Scope of applicability & $\begin{array}{l}\text { Is the method/technique applicable to the } \\
\text { different layers of software:Application, } \\
\text { middleware, and infrastructure? }\end{array}$ \\
\hline & Application domain independency & $\begin{array}{l}\text { Is the method limited to any application } \\
\text { domain? }\end{array}$ \\
\hline & Component-specificity & $\begin{array}{l}\text { Can the method be used to predict the reliability } \\
\text { and availability of theindividual components? } \\
\text { How does the method/technique treat black box } \\
\text { components? }\end{array}$ \\
\hline & Architecture-specificity & $\begin{array}{l}\text { Can the method/technique be applied to } \\
\text { software systems that are distributed to several } \\
\text { (hardware) platforms? Are the different } \\
\text { interactions between components considered? }\end{array}$ \\
\hline & $\begin{array}{l}\text { Platform/implementation technology } \\
\text { independency }\end{array}$ & $\begin{array}{l}\text { Can the method/technique be used before } \\
\text { making any implementation-related decisions? } \\
\text { Is the method dependent on a certain platform } \\
\text { or implementation technology? }\end{array}$ \\
\hline \multirow{4}{*}{ User } & Target group & Who is the intended user of the method? \\
\hline & Needed skills & What skills are required for using the method? \\
\hline & Expected benefits & What are the benefits of using the method? \\
\hline & Required resources & $\begin{array}{l}\text { How much extra work does the method require? } \\
\text { How much time doesthe use of the method } \\
\text { require? }\end{array}$ \\
\hline \multirow{8}{*}{ Contents } & Language & $\begin{array}{l}\text { What notation is used in architecture } \\
\text { descriptions? }\end{array}$ \\
\hline & Architectural viewpoints & $\begin{array}{l}\text { What views does the method use for predicting } \\
\text { reliability and availability?How is the behavior } \\
\text { modeled? }\end{array}$ \\
\hline & Analysis model & $\begin{array}{l}\text { Does the method provide a special model with } \\
\text { which the analysis isperformed? }\end{array}$ \\
\hline & System usage & $\begin{array}{l}\text { Have the different ways and frequencies that } \\
\text { were used for executingtasks been taken into } \\
\text { account? }\end{array}$ \\
\hline & Variability & $\begin{array}{l}\text { Is the variation of architecture considered in the } \\
\text { analysis? Can theanalysis be performed for } \\
\text { different product variants by reusing existing } \\
\text { knowledge? }\end{array}$ \\
\hline & Tool support & Are there any tools that support the method? \\
\hline & Analysis process & $\begin{array}{l}\text { How the analysis is performed (the inputs, } \\
\text { outputs and techniques)? }\end{array}$ \\
\hline & Limitations & $\begin{array}{l}\text { What are the assumptions and limitations of the } \\
\text { method? }\end{array}$ \\
\hline Validation & Maturity of the method & $\begin{array}{l}\text { When was the material of the method first } \\
\text { published? Has the method been applied in the } \\
\text { lab only or also in the development of large- } \\
\text { scale products? How many times and to what } \\
\text { size of applications has the method been } \\
\text { applied? Is there evidence for the method's } \\
\text { benefits and costs? }\end{array}$ \\
\hline
\end{tabular}


Table1. Continued

\begin{tabular}{|c|c|c|}
\hline & $\begin{array}{l}\text { Traceability of } \mathrm{R} \& \mathrm{~A}(\text { Reliability } \& \\
\text { Availability) requirements }\end{array}$ & $\begin{array}{l}\text { When was the material of the method first } \\
\text { published? Has the method been applied in the } \\
\text { lab only or also in the development of large- } \\
\text { scale products? How many times and to what } \\
\text { size of applications has the method been } \\
\text { applied? Is there evidence for the method's } \\
\text { benefits and costs? }\end{array}$ \\
\hline & Precision of prediction & $\begin{array}{l}\text { How close are the predicted values to the actual } \\
\text { values when the method has been used? }\end{array}$ \\
\hline
\end{tabular}

\section{OVERVIEW OF RELIABILITY AND AVAILABILITY PREDICTION APPROACHES}

At a high level of abstraction, the reliability and availability analysis methods can be classified into quantitative and qualitative methods. Methods employing quantitative techniques have been used since the 1970s [5]. There is a lot of variation in the quantitative methods; some of the methods are applicable before, and some after, system implementation. System measurement based methods, which focus on failures and down times, are used for analyzing systems already in use and for making predictions on implemented systems that are usually run and tested in a lab. The effort in software reliability growth based models [20] is concentrated on statistical testing, and therefore the models are applicable in the late development phase. These types of methods are called black-box approaches, since they ignore the internal structure of software systems. Since today's software systems are based on components and their interactions, these methods do not encompass the reliability and availability prediction of component based software architectures. The so-called whitebox approaches consider the system's internal structure in reliability prediction, computing the system level reliability based on the reliabilities of its components. GosevaPopstojanova and Trivedi[6] provide a useful survey of architecture based approaches, categorizing them into statebased, path-based and additive models. The state-based models use the probabilities of the transfer of control between components to estimate the system reliability, whereas the path-based models compute the reliability of composite software based on the possible execution paths of the system. The additive models address the failure intensity of composite software, assuming that the system failure intensity can be calculated from component failure intensities. The additive models, however, model failure intensities with mathematical algorithms, and therefore do not explicitly examine software architectures. The earliest methods of state-based and path based models [5] were proposed in the 1970s and new methods have evolved since then.

Qualitative analysis methods manipulate knowledge rather than numbers. This knowledge is usually specific for the system under study and can be explicit, i.e. documented; or tacit, undocumented. The tacit knowledge is only in the designers' mind, which makes the analysis process highly human dependent and therefore prone to errors. Knowledge can also be abstract/general, or domain/application specific. Recently, there has been a tendency to document general knowledge, for example, by identifying and using architectural styles and patterns. There still exists a considerable lack of architectural styles and patterns that concentrate on solving the problems of reliability and availability.

\section{COMPARISON OF RELIABILITY AND AVAILABILITY PREDICTION METHODS}

Since numerous analysis methods are available for reliability. Hence we are defining the scope for the methods. Selections are made on the following basis.

$$
\begin{aligned}
& \text { - Concentrating on software reliability and/or } \\
& \text { availability } \\
& \text { - } \quad \text { Based on architectural view } \\
& \text { - } \quad \text { Pser centric approaches for analysis } \\
& \text { Provide clear and applicable analysis }
\end{aligned}
$$

Tables 2 and 3 represent the detailed comparison results of the selected six methods.

Table 2.Comparison summary of reliability analysis methods (part1/2)

\begin{tabular}{|l|l|l|l|}
\hline Elements & Cortellessa et al. [7] & Rodrigues et al. [8] & Yacoub et al. [9] \\
\hline Goal & $\begin{array}{l}\text { To predict system reliability } \\
\text { based on component and } \\
\text { connector failure rates }\end{array}$ & $\begin{array}{l}\text { To predict software system } \\
\text { reliability taking into account } \\
\text { the component structure that } \\
\text { is exhibited in the scenarios } \\
\text { and concurrent nature of } \\
\text { systems }\end{array}$ & $\begin{array}{l}\text { To analyze the reliability of } \\
\text { fomponent-based applications as a } \\
\text { interfaces }\end{array}$ \\
\hline Scope of applicability & $\begin{array}{l}\text { Focused on the application } \\
\text { layer but can also be applied } \\
\text { toother layers of software }\end{array}$ & $\begin{array}{l}\text { Not designed for any specific } \\
\text { software layer }\end{array}$ & $\begin{array}{l}\text { Designed to the application layer; can } \\
\text { be applied to otherlayers as well }\end{array}$ \\
\hline
\end{tabular}


Table 2. Continued

\begin{tabular}{|c|c|c|c|}
\hline $\begin{array}{l}\text { Applicationdomain } \\
\text { independency }\end{array}$ & $\begin{array}{l}\text { Domain undefined, may be } \\
\text { applied to any domain }\end{array}$ & $\begin{array}{l}\text { Domain undefined, may be } \\
\text { applied to any domain }\end{array}$ & $\begin{array}{lcc}\text { Targeted } & \text { to } & \text { all } \\
\text { componentbasedapplications } & \end{array}$ \\
\hline Component-specificity & $\begin{array}{l}\text { Assumes that reliability } \\
\text { estimates of the components } \\
\text { are available }\end{array}$ & $\begin{array}{l}\text { Assumes that reliability } \\
\text { estimates of the components } \\
\text { are available }\end{array}$ & $\begin{array}{l}\text { Assumes that reliability estimates of } \\
\text { the components are available }\end{array}$ \\
\hline Architecture-specificity & 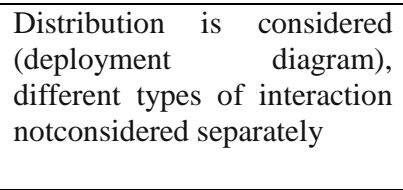 & $\begin{array}{l}\text { Different interaction types not } \\
\text { considered but all of them can } \\
\text { easily be described in } \\
\text { scenariodescriptions. } \\
\text { Distribution not discussed }\end{array}$ & $\begin{array}{l}\text { Distribution is considered as link } \\
\text { reliabilities. Component interactions } \\
\text { are described as dependencies } \\
\text { (adapted from control flow graph) }\end{array}$ \\
\hline $\begin{array}{l}\text { Platform/implementation } \\
\text { technology independency }\end{array}$ & Implementation independent & Implementation independent & Implementation independent \\
\hline Target group & System architects & $\begin{array}{l}\text { Method user not defined, } \\
\text { likely targeted to software } \\
\text { architects }\end{array}$ & Software architects \\
\hline Needed skills & No special skills needed & $\begin{array}{lll}\begin{array}{l}\text { Familiarity with } \\
\text { chains }\end{array} & \text { Markov } \\
\end{array}$ & No special skills needed \\
\hline Expected benefits & $\begin{array}{l}\text { Reliability analysis before } \\
\text { implementation. Allows } \\
\begin{array}{l}\text { selection of elements with } \\
\text { suitable reliability } \\
\text { characteristics }\end{array} \\
\end{array}$ & $\begin{array}{l}\text { Reliability analysis before } \\
\text { implementation. Detection of } \\
\text { mismatch between behavior } \\
\text { and architecture }\end{array}$ & $\begin{array}{l}\text { Detection of the influence of usage } \\
\text { scenarios on reliability } \\
\begin{array}{l}\text { of of } \\
\text { components. } \\
\text { reliability }\end{array}\end{array}$ \\
\hline Required resources & $\begin{array}{l}\text { Fully integrated with UML } \\
\text { (Unified Modeling Language) } \\
\text { the annotation of diagrams } \\
\text { requires only slight additional } \\
\text { work. Due to the tool support } \\
\text { promised some extra time } \\
\text { required }\end{array}$ & $\begin{array}{l}\text { First, the scenario annotations } \\
\text { must be performed, the rest of } \\
\text { the analysis is partly } \\
\text { automated. Tool support for } \\
\text { synthesis of LTS (Labeled } \\
\text { Transition System) models. } \\
\text { Several tools for analysis } \\
\text { based on Markov chains }\end{array}$ & $\begin{array}{l}\text { Time to estimate the analysis model } \\
\text { parameters and construct the CDG } \\
\text { (Component Dependency Graph) } \\
\text { depends on the size and complexity of } \\
\text { the system. The calculations are } \\
\text { automated }\end{array}$ \\
\hline Language & UML & $\begin{array}{l}\text { MSC as scenario notations, } \\
\text { architecture description is not } \\
\text { set to any particular notation }\end{array}$ & UML \\
\hline $\begin{array}{l}\text { Architectural } \\
\text { viewpoints }\end{array}$ & $\begin{array}{l}\text { Architecture is modeled with } \\
\text { use case, sequence, and } \\
\text { deployment diagrams }\end{array}$ & $\begin{array}{l}\text { Behavior is modeled with } \\
\text { scenarios }\end{array}$ & $\begin{array}{l}\text { Sequence diagrams are adopted as a } \\
\text { means of documenting scenarios }\end{array}$ \\
\hline Analysis model & Annotations & $\begin{array}{l}\text { Annotations, Cheung's model } \\
\text { (i.e. Markov chains) }\end{array}$ & CDG \\
\hline System usage & $\begin{array}{l}\text { Different user profiles with } \\
\text { related occurrence } \\
\text { probabilities are detected } \\
\text { from annotated use case } \\
\text { diagram }\end{array}$ & 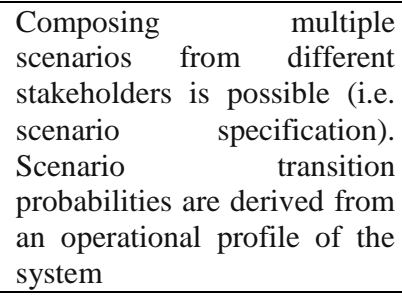 & $\begin{array}{l}\text { Based on scenarios. Component } \\
\text { execution probabilities assigned to } \\
\text { scenarios are similar to the } \\
\text { operational profile }\end{array}$ \\
\hline Variability & Not supported & Not supported & Not supported \\
\hline Tool support & $\begin{array}{l}\text { Working currently on a set of } \\
\text { automation tools }\end{array}$ & $\begin{array}{l}\text { Tool support exists for the } \\
\text { automation of a synthesis of } \\
\text { LTS models. }\end{array}$ & $\begin{array}{l}\text { The calculation algorithm is } \\
\text { automated }\end{array}$ \\
\hline Analysis process & $\begin{array}{l}\text { Input: } \quad \text { annotations, } \\
\text { Technique: calculation } \\
\text { formulas, } \\
\text { Output: component and } \\
\text { system failure probabilities }\end{array}$ & $\begin{array}{l}\text { Input: Annotated MSCs, } \\
\text { LTSs synthesized for each } \\
\text { component, } \\
\text { Technique: Markov model, } \\
\text { Output: System reliability } \\
\text { estimate, detected implied } \\
\text { scenarios }\end{array}$ & $\begin{array}{l}\text { Input: Parameter (attribute) estimates, } \\
\text { Technique: CDG, SBRA algorithm, } \\
\text { Output: reliability of application as } \\
\text { the function of reliability of } \\
\text { components and transitions }\end{array}$ \\
\hline
\end{tabular}

Table 2. Continued 


\begin{tabular}{|c|c|c|c|}
\hline Limitations & $\begin{array}{l}\text { components must be } \\
\text { available. Independence of } \\
\text { failures among different } \\
\text { components }\end{array}$ & $\begin{array}{l}\text { components has the Markov } \\
\text { property. Failures are } \\
\text { independent across } \\
\text { transitions. There is only one } \\
\text { initial and one final scenario } \\
\text { for a system. Component } \\
\text { reliability must be available }\end{array}$ & $\begin{array}{l}\text { component reliability must be } \\
\text { available. Does not consider failure } \\
\text { dependencies between components or } \\
\text { take into account the overall } \\
\text { application reliability growth as a } \\
\text { function of time }\end{array}$ \\
\hline Maturity of method & $\begin{array}{l}\text { Validation is based on } \\
\text { experimental evaluation } \\
\text { performed by the authors }\end{array}$ & $\begin{array}{l}\text { Validation is based on } \\
\text { empirical evaluation } \\
\text { performed by the authors }\end{array}$ & $\begin{array}{l}\text { An experimental case study is used to } \\
\text { illustrate the applicability of the } \\
\text { approach }\end{array}$ \\
\hline $\begin{array}{l}\text { Traceability of R\&A } \\
\text { requirements }\end{array}$ & Not supported & Not supported & Not supported \\
\hline Precision of prediction & $\begin{array}{l}\text { Not compared with actual } \\
\text { values }\end{array}$ & $\begin{array}{l}\text { Not compared with actual } \\
\text { values }\end{array}$ & Not compared with actual values \\
\hline
\end{tabular}

Table 3.Comparison summary of reliability analysis methods (part 2/2)

\begin{tabular}{|c|c|c|c|}
\hline Elements & Reussner et al. [1] & Grassi [10] & Wang et al. [11] \\
\hline Goal & $\begin{array}{l}\text { To predict system reliability } \\
\text { through compositional } \\
\text { analysis of usage profiles } \\
\text { and the reliability of } \\
\text { environment components }\end{array}$ & $\begin{array}{l}\text { To predict the dependability } \\
\text { (inc. reliability) of an } \\
\text { assembly of pre-existing } \\
\text { independently developed } \\
\text { services }\end{array}$ & $\begin{array}{l}\text { To predict the reliability of } \\
\text { heterogeneous systems according to } \\
\text { reliability of each component, } \\
\text { operational profile and the } \\
\text { architecture of software }\end{array}$ \\
\hline Scope of applicability & $\begin{array}{l}\text { Proposed for service } \\
\text { architecture but may also be } \\
\text { used for other layers }\end{array}$ & $\begin{array}{l}\text { Intended for service-oriented } \\
\text { computing (SOC) systems }\end{array}$ & $\begin{array}{l}\text { Designed mainly for the application } \\
\text { layer but is applicable to the other } \\
\text { layers }\end{array}$ \\
\hline $\begin{array}{ll}\text { Application } & \text { domain } \\
\text { independency } & \end{array}$ & $\begin{array}{l}\text { Domain undefined, may be } \\
\text { applied to any domain }\end{array}$ & $\begin{array}{l}\text { Domain undefined, may be } \\
\text { applied to any domain }\end{array}$ & $\begin{array}{l}\text { Domain undefined, may be applied } \\
\text { to any domain. }\end{array}$ \\
\hline Component-specificity & $\begin{array}{l}\text { Reliability of a component is } \\
\text { computed as a function of } \\
\text { the usage profile and the } \\
\text { reliability of external } \\
\text { services. Can also be used } \\
\text { for black-box components }\end{array}$ & $\begin{array}{l}\text { Assumes that reliability of } \\
\text { basic resources (i.e. services } \\
\text { that do not require other } \\
\text { services) is known. Predicts } \\
\text { reliability of complex } \\
\text { resources (i.e. services that } \\
\text { require other services to } \\
\text { carry out their own services) }\end{array}$ & $\begin{array}{l}\text { Assumes that reliability estimates of } \\
\text { the components are available }\end{array}$ \\
\hline Architecture-specificity & $\begin{array}{l}\text { Use and control interactions } \\
\text { are supported. Applicable to } \\
\text { open, distributed systems } \\
\text { (hierarchical kens define } \\
\text { distribution boundaries) }\end{array}$ & $\begin{array}{l}\text { Interactions are described as } \\
\text { flows of requests between } \\
\text { services. Distribution is } \\
\text { supported as flows } \\
\text { associated with connectors }\end{array}$ & $\begin{array}{l}\text { Interactions are described as } \\
\text { transitions between components. } \\
\text { Distribution is not considered }\end{array}$ \\
\hline $\begin{array}{l}\text { Platform/implementation } \\
\text { technology independency }\end{array}$ & Implementation independent & $\begin{array}{l}\text { Implementation independent. } \\
\text { However, based on } \\
\text { preexisting services. } \\
\text { Resources are not limited to } \\
\text { software resources }\end{array}$ & Implementation independent \\
\hline Target group & Software integrators & Service assemblers & Software architects \\
\hline Expected benefits & $\begin{array}{l}\text { Reliability analysis of } \\
\text { components, architecture, } \\
\text { and environment }\end{array}$ & $\begin{array}{l}\text { Enables to select reliable } \\
\text { services when assembling } \\
\text { services. }\end{array}$ & $\begin{array}{l}\text { Enables to analyze the reliability of a } \\
\text { system that combines heterogeneous } \\
\text { architectural styles }\end{array}$ \\
\hline
\end{tabular}

Table 3. Continued

\begin{tabular}{|l|l|l|l|}
\hline & & Transformation of the architectural \\
Required resources & $\begin{array}{l}\text { Development of Markov } \\
\text { chains for kens/composite }\end{array}$ & $\begin{array}{l}\text { Development of different models. Not easily } \\
\text { three }\end{array}$ & $\begin{array}{l}\text { views into state views, computation reliability and transition } \\
\text { of } \\
\text { kens. Not easily applicable } \\
\text { applicable (time-consuming) } \\
\text { probability of each state, integration } \\
\text { (time-consuming) if the } \\
\text { calculations the calculations are not of the views. Time-consuming } \\
\text { method if the state views do not }\end{array}$ \\
\hline
\end{tabular}


Volume 72-No.5, May 2013

\begin{tabular}{|c|c|c|c|}
\hline & automated & & $\begin{array}{l}\text { already exist, or tool support is not } \\
\text { provided }\end{array}$ \\
\hline Language & 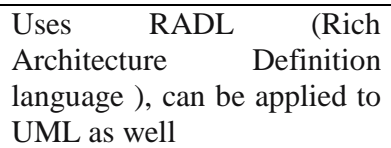 & $\begin{array}{l}\text { Does not require any specific } \\
\text { architecture notation }\end{array}$ & $\begin{array}{l}\text { Does not require any specific } \\
\text { architecture notation }\end{array}$ \\
\hline $\begin{array}{l}\text { Architectural } \\
\text { viewpoints }\end{array}$ & $\begin{array}{l}\text { Describes architecture as a } \\
\text { composition of kens }\end{array}$ & $\begin{array}{l}\text { Describes architecture as an } \\
\text { assembly of services }\end{array}$ & $\begin{array}{l}\text { Architecture described as } \\
\text { components and connectors }\end{array}$ \\
\hline Analysis model & Markov chains & $\begin{array}{l}\text { Flows of request are } \\
\text { modeled by a discrete time } \\
\text { Markov } \\
\text { chain }\end{array}$ & Markov chains \\
\hline System usage & $\begin{array}{l}\text { Usage profiles are modeled } \\
\text { as probabilities of calls to a } \\
\text { provided service in a certain } \\
\text { state }\end{array}$ & $\begin{array}{l}\text { Services of complex } \\
\text { resources are characterized } \\
\text { by a flow modeling the } \\
\text { usage profile of other } \\
\text { services }\end{array}$ & $\begin{array}{l}\text { Operational profile is taken into } \\
\text { account as transition probabilities } \\
\text { between components }\end{array}$ \\
\hline Variability & Not supported & Not supported & Not supported \\
\hline Tool support & Not provided & Not provided & Not provided \\
\hline Analysis process & $\begin{array}{l}\text { Input: the reliability of basic } \\
\text { kens, service FSMs, and } \\
\text { usage profiles of provided } \\
\text { services, } \\
\text { Technique: Markov chains, } \\
\text { Output: Service reliability } \\
\text { and overall reliability }\end{array}$ & $\begin{array}{l}\text { Input: failure information of } \\
\text { the service flows, } \\
\text { Technique: Markov chains, } \\
\text { flow model, } \\
\text { Output: reliability of a } \\
\text { service as the reliability of } \\
\text { the services it requires }\end{array}$ & $\begin{array}{l}\text { Input: integrated global state view of } \\
\text { the system, Technique: transition } \\
\text { Matrix, Output: reliability of the } \\
\text { system }\end{array}$ \\
\hline Limitations & $\begin{array}{l}\text { Requires certain data for the } \\
\text { architectural kens. Failures } \\
\text { of services are independent }\end{array}$ & $\begin{array}{l}\text { The failure rate of basic } \\
\text { resources is known. Each } \\
\text { request in a state must be } \\
\text { fulfilled according to some } \\
\text { completion models before a } \\
\text { transition to the next state } \\
\text { can take place }\end{array}$ & $\begin{array}{l}\text { Assumes that the reliabilities of } \\
\text { components and connectors are } \\
\text { independent of the transition } \\
\text { probabilities }\end{array}$ \\
\hline Maturity of method & $\begin{array}{l}\text { Validation is based on } \\
\text { empirical evaluation } \\
\text { performed by the authors }\end{array}$ & $\begin{array}{l}\text { Validation is based on a } \\
\text { laboratory example used for } \\
\text { illustrating the approach }\end{array}$ & $\begin{array}{l}\text { Validation is based on experiments } \\
\text { performed by the authors }\end{array}$ \\
\hline $\begin{array}{l}\text { Traceability } \\
\text { R\&Arequirements }\end{array}$ & Not supported & Not supported & Not supported \\
\hline Precision of prediction & $\begin{array}{l}\text { In the example system, the } \\
\text { deviation of the prediction } \\
\text { from the measured value is } \\
\text { below } 1 \%\end{array}$ & $\begin{array}{l}\text { Not compared with actual } \\
\text { values }\end{array}$ & Not compared with actual values \\
\hline
\end{tabular}

\section{RESULTS OF THE COMPARISON}

Reliability and availability, as well as other quality attributes, have just recently begun to be addressed at the architecture level methods, techniques and notations. Design approaches already exist that use quality attributes as primary requirements when designing software architecture [1], [12]. It has also been recognized that analysis from the architecture is only possible if the architecture is represented in a way that enables the analysis [13]. A standard notation extension is required in order to unify the different analysis methods and to avoid the development of an enormous amount of separate annotation and extension techniques. All of the surveyed methods require some additional work, mostly regarding the development of an analysis model or application of mathematical algorithms. It is obvious that approaches closer to UML require less additional work as UML being a widely used standard, and therefore, are more familiar to architects working in industry than the approaches that require a separate analysis model. It is also obvious that more tool support is needed in order to make reliability prediction a fluent part of software development. The study could not find any method that would also consider variability in the analysis. None of the existing methods provides traceability of $\mathrm{R} \& \mathrm{~A}$ requirements to predicted $\mathrm{R} \& \mathrm{~A}$, against which the measured R\&A should be compared. The analysis approaches studied above do not analyze component reliability or do not consider the effect of a component's internal behavior on its reliability. The availability analysis methods are very scarce; except two methods [14], [15]. The availability analysis has not been studied, or at least, we could not find any evidence. One reason is the confusing definitions of the ISO/IEC 9126-1 quality model [16] that defines reliability as the capability of a software system to maintain a specified level of performance when used under the specified conditions. According to the quality model, reliability is mixed with performance, and availability is a sub-characteristic of reliability. This partly explains why only a few availability analysis methods exist. 


\section{CONCLUSIONS}

Based on our literature survey, the paper concludes that the current analysis methods have several shortcomings limiting their use in industrial settings. The most common shortcomings were a lack of support for tools and variability, weak reliability analysis of software components, and weak validation of the methods and their results. In addition, there was no proof of the maturity of the methods as they were not validated or used in the industry. Furthermore, quantitative methods alone cannot provide a comprehensive prediction of the reliability and availability of a system. The comparison process using the framework was straightforward and simple. The framework is a valuable tool for anyone searching for an applicable analysis method. Based on the comparison using the framework the best suitable analysis method can be selected. The framework assists to pay attention to important issues of the analysis methods from the viewpoint of software architecture. Although the framework was not applied to availability analysis methods, but still believe that the framework is suitable for the evaluation methods of any quality attribute because its elements have been defined according to the needs of architectural evaluation, not from the viewpoint of any specific quality attribute. The framework also takes into account variability, the specific characteristic of product family architectures that are increasingly applied to software intensive systems in industry. In summary, future research activities are needed for developing availability analysis methods applicable for service oriented architectures, a standard notation describing reliability, availability and their variations in architectural descriptions, and for improving architecture modeling and analysis tools which are needed for providing architects with an integrated working environment. The main benefit of an integrated environment is that it enables the achievement of a better traceability of reliability and availability requirements, and therefore, a better applicability of the methods for large software products in the industry.

\section{REFERENCES}

[1] Reussner, R.H., Schmidt, H.W., Poernomo, I.H.: Reliability prediction for component-based software architectures. J. Systems Softw. 66(3), 241-252 (2003)

[2] Avizienis, A.,Laprie, J.C.,Randell,B.: Fundamental Concepts of Dependability. LAAS-CNRS. p. 21 (2001)

[3] Lyu, M. R. (2007), Software Reliability Engineering, A Roadmap, in proceedings of international conference on Future of Software Engineering, Washington, pp.153170.

[4] Jayaratna, N.: Understanding and Evaluating Methodologies: NIMSAD: a Systematic Framework. McGraw Hill, London, 259 p (1994)

[5] Shooman, M.: Structural models for software reliability prediction. In: Proceedings of the 2nd International Conference on Software Engineering (1976)

[6] Goseva-Popstojanova, K., Trivedi, K.S.: Architecture based approach to reliability assessment of software systems. Perform. Evaluat. 45(2-3), 179-204 (2001)
[7] Cortellessa, V., Singh, H., Cukic, B.: Early reliability assessment of UML based software models. In: Third International Workshop on Software and Performance. Rome (2002)

[8] Rodrigues, G.N., Rosenblum, D.S., Uchitel, S.: Using scenariosto predict the reliability of concurrent component-basedsoftware systems. In: 8th International Conference on Fundamental Approaches to Software Engineering, FASE 2005. Springer Lecture Notes in Computer Science, Edinburgh,(2005).

[9] Yacoub, S., Cukic, B., Ammar, H.: Scenario-based reliability analysis of component-based software. In: Proceedings of 10th International Symposium on Software Reliability Engineering (ISSRE'99) (1999).

[10] Grassi, V.: Architecture-based dependability prediction for service-oriented computing. In: Proceedings of the Twin Workshops on Architecting Dependable Systems, International Conference on Software Engineering (ICSE 2004). Springer, Edinburgh, (2004)

[11] Wang, W.-L., Wu, Y., Chen, M.-H.: An architecture based software reliability model. In: Pacific Rim International Symposium on Dependable Computing. IEEE, Hong Kong (1999)

[12] Bachmann, F., Bass, L., Klein, M.: Moving from quality attribute requirements to architectural decisions. In: Second International Software Requirements to Architectures, STRAW'03. Portland, USA (2003)

[13] Jazayeri, M., Ran, A., van der Linden, F.: Software Architecture for Product Families. Addison-Wesley, Boston, 257 p (2000)

[14] Laprie, J.C., Kanoun, K.: X-ware reliability and availability modeling. IEEE Trans. Software Eng. 18(2), 130-147 (1992)

[15] Ledoux, J.: Availability modeling of modular software. IEEE Trans. Reliability 48(2), 159-168 (1999)

[16] ISO/IEC, Software Engineering - Product Quality. Part 1: Quality Model (2001)

[17] Suri, P.K. (2009), Simulator for Risk assessment of software project based on performance measurement, International Journal of Computer Science and Network Security, Vol.9 No.6, pp. 23-30.

[18] Taylor, R. and Vander, Hoek A. (2007), Software Design and Architecture: The Once and Future Focus of Software Engineering, International conference on Future of Software Engineering, IEEE-CS Press, pp. 226-243

[19] Yadav, A. and Khan R.A.(2009), Critical review on software reliability models, International Journal of recent trends in Engineering, Vol 2, No. 3, pp. 114-116.

[20] Yamada, S., Ohtera, H. and Narihisa, H. (1986), Software Reliability Growth Models with Testing-Effort, IEEE Trans. Reliability, Vol. 35, pp. 19-23. 